\title{
13 Sub-Saharan Migrants' Masculinities: An Intersectional Analysis of Media Representations during the Libyan War 2011
}

\author{
Maria DeVargas and Stefania Donzelli ${ }^{1}$
}

\begin{abstract}
Studies of the role of the media in conflict situations have brought to the fore the significance of representations as an important part of the process of knowledge production about wars and the actors involved. The media can influence interpretations and framing of conflicts, moulding specific understandings of their causes and modalities of intervention. The Libyan war in $20 \mathrm{II}$ is an interesting case to reflect on the United Nations (UN) principle of Responsibility to Protect (RtoP), and how conflict affects those populations who occupy a subordinate position in multiple stratification systems (gender, race, and class), whether they are locked in conflict zones or are trying to join the flow of people fleeing across borders. In the context of humanitarian intervention, specific understandings of the migrants as social subjects become strongly correlated with corresponding support mechanisms. This chapter conducts an intersectional analysis to provide a perspective on the politics of the media representation of 'migrants' in Libya, discerning the key links between the constructions of their masculinities and the practices of protection for 'people on the move'. We show how, being situated at the bottom of the social hierarchy in Libya, sub-Saharan black Africans were inappropriately presented in media coverage during the initial phase of the conflict as subjects of adequate protection. Their invisibilization and subordination by the media have been largely framed within international political and economic interests, which have also reinforced the idea of the international community as the legitimate protector of civilians. We argue that these representations reproduce migrants' vulnerability and, by placing them in a situation of triple jeopardy (structural, political, and representational), undermine the possibility of conceiving and understanding security beyond their 'naturalized' victimization and subordination.
\end{abstract}

Keywords: Masculinities, intersectionality, media representations, sub-Saharan migrants, Libya, human security.

\subsection{Introduction}

Following the United Nations' report Human Security Now (Commission on Human Security/UNOPS 2003), the Responsibility to Protect (RtoP) has now become the main normative framework for approach-

1 Authors' names are indicated in alphabetical order as their contributions to the paper are considered equally valuable. Maria DeVargas works as Researcher Assistant and Project Officer for the project promoting this book at the International Institute of Social Studies (ISS), Erasmus University Rotterdam. She is a psychologist with a Master's in Development Studies at ISS. Stefania Donzelli is a Ph.D. researcher at the International Institute of Social Studies (ISS), Erasmus University Rotterdam. Her main research project focuses on migration, feminism, and social movements. ing human vulnerabilities and international community interventions (Fukuda-Parr/Messineo 20I2). While human security thinking is mainly concerned with the multidimensional impacts of threats to peoples, communities, and individuals, and is complementary to thinking on state security, the RtoP relates specifically to how the international community - employing a variety of means, including military ones can prevent and stop genocides, war crimes, ethnic cleansing and crimes against humanity occurring in internal conflicts (Hoogensen/Stuvoy 2006; Saxer 2008). These normative frames when associated to migration, "treat security as a value or condition" to be achieved by people on the move. In doing so, they move beyond the traditional understanding of state security, recognizing that "political concerns regarding security and mi- 
gration have shifted beyond the state to the transnational and global level" (Huysman/Squire 2009: 5).

Among the factors influencing access to security, social relations of power delineated by gender play a fundamental role. A consistent body of literature, emerging in the last decade, has focused on the relationships between women, gender, and the international security agenda, particularly UN Security Council Resolution 1325 introduced in 200I (Carey 200I; McKey 2004; Hudson 20IO; Heathcote 20II). Some authors have entered the debate focusing on the variety of forms of insecurity faced by women in conflict situations and while on the move, and showing women as actors who can help to create a more positive environment for social well-being (Hill/Aboitiz/ Poehlman-Doumbouya 2003; Pezzotti 2005). Others have broadened the meaning of security to cover many complex global problems beyond its conventional understanding, including environmental issues, HIV/AIDS, and economic crises (Scheffran/Brzoska/ Brauch/Link/Schilling 20I2; Gasper 20IO; Truong 2009; Kristoffersson 2000). In general, most scholars using the concept of gender have focused on women, and have failed to develop more comprehensive approaches to men and masculinities. Yet, as shown by Das (2008), empirical research has highlighted that attention to gendered differences in terms of constructions of masculinities and femininities can illuminate the complexity of situations of vulnerability. Such broader understandings of gender analyses, as Hoogensen and Stuvoy (2006) argue, have the potential to expand the definition of security from bottom-up perspectives by drawing attention to subjective experiences and allowing more complex comprehensions of the determinants of human insecurities. However, in order to open spaces for people-centred meanings of security, we claim the importance of deconstructing the dominant understanding of those considered subjects of protection as conveyed in public discourses. In fact, by showing problematic aspects of dominant discourses, we aim to highlight the importance of bottom-up voices to promote a debate on how identity constitutes a key element in articulating relationships of security and protection, and also on how subjects of protection as political actors in their own right can construct more inclusive forms of protection.

This chapter seeks to contribute to this literature by examining the links between migration, media construction of masculinities, and human security, focusing on the war in Libya in 20II, which triggered a critical migration emergency in the region. Our core concern relates to the role and influence of media representations in socially constructing sub-Saharan black Africans' identities. We argue that by reinforcing their status of multiple subordinations, these media representations contributed to reducing their access to protection while fleeing the Libyan conflict or sheltering from violent situations. For our purposes, we do not focus on evaluating the limits and merits of relief programmes developed in the context of Human Security and RtoP, but we seek to reflect on the media's function in implicitly communicating proposals about who should get access to these programmes and how and why they should get it, as well as in legitimating the underlying normative frames.

In order to enter the debate on who gets access to security, this study comprehends the meaning of 'border' as not limited to sovereignty and territoriality, but also as the demarcation of legal and social boundaries that allow different identities and groups to be defined as subjects of protection. In these terms, the meaning of border as the legal boundary of being a 'refugee', 'migrant worker', or 'expatriate staff' needs to be exposed so that definitions of accountability and norms as used by humanitarian organizations to administer evacuation and provide protection can be grasped. Similarly, the understanding of borders as cultural, ethnic, and racial frontiers arising from intergroup dynamics allows us to discern the different pathways through which people become 'locked into' a conflict zone, or are made socially visible as human subjects in need of protection. Exposing such legal and social meanings of boundaries and the particular value systems on which they are based, this chapter reflects on a constitutive element of the 'politics of representation' ${ }^{2}$ relevant to achieving more egalitarian justice, namely constructions of differential locations and forms through which diverse groups access protection, while others grant it (Fraser 2009). In this sense, the analysis of boundaries among collective identities presented in media information becomes relevant to issues of 'protection' in so far as the common representational strategies used by the media designate particular groups as 'subjects' to be protected or as responsible for protecting others. In other words, the representation of actors involved in conflict through such strategies as naturalization, normalizing, categorization, or framing entails the construction of the accountability of subjects, politics,

2 For readers unfamiliar with the concept, this 'politics of representation' or media representations means the forms in which media present identities and realities of different subjects and events. 
and actions in the field of human security (Hall I997; Leudar/Marsland/Nekvapil 2004; Zarkov 20II).

In Libya, the group of black people and sub-Saharan black Africans is a heterogeneous population, internally stratified by race/ethnicity, age, religion, class, sense of loyalty, nationality, and history of migration into the country. They also constitute a highly gendered group of migrants, in the sense that a considerable majority are male as men are more easily integrated into the construction, agriculture, and oil sectors offered by the Libyan labour market. Their treatment and subordination have been largely determined $^{3}$ by intersectional and dynamic patterns of violence related to the unfolding of the conflict. However, in addressing how the media construct subSaharan black Africans' masculinities in connection with the Libyan conflict, it is important to observe how, despite their diverse social locations, they tend to be homogenized by race/ethnicity along the lines of a 'threat' to different actors, and how this undermines their entitlements to security and protection as human subjects under international norms.

Studies of media and conflict have pointed out the significant role and risky implications of media categorization and other representational strategies regarding the selective exposure and characterization of certain actors and their particular conditions, which provide moral accounts and justification for particular actions (Hall I997; Zarkov 20II; Tucker/Triantafyllos 2008; Fudge 20IO). Media, located within the broader frameworks of contemporary processes of globalization and relying on discourses and forms of representation embedded in global societal power relations, propose specific understandings of international involvement, and may support non-intervention or call for action (Hall I997; Didero 20II; Fraser 2009). In vi-

3 This group of population includes Libyan citizens and foreigners in transit, with temporary or permanent status. In addition to their nationality and migratory status, the class elements are relevant to defining their position in the Libyan social hierarchy according to their education and type of job. It is also important to contemplate the diversity of race because not all come under the labels of black race or sub-Saharan ethnic groups. However, political and conflict dynamics define a large part of their treatment. For example: a black African who has Libyan nationality and is loyal to Gaddafi is in a very different position to a sub-Saharan black African migrant worker, or one who is in transit to Europe, or one detained by Gaddafi under his agreement with Italy on extra-territorial control. However, during the conflict the pattern of actions taken against black 'mercenaries' affected all the black population. olent conflicts, media construct perpetrators and victims in dichotomous ways, and often the information presented is unable to capture the cultural and structural dynamics behind processes producing intersectional identities, multi-layered belonging and affiliated vulnerability within conflict zones and during the process of fleeing. This makes the application of norms of protection by the 'protectors' a dubious area that must be subject to scrutiny towards the assembly of more egalitarian perspectives on justice.

To develop this argument, the chapter firstly discusses the theoretical posture on intersectionality elaborated by Crenshaw and its relevance to reflecting on the representation of sub-Saharan masculinities during the conflict. It then presents the preconditions for migrants' vulnerability in Libya, showing how systematic discrimination against them, emerging also from the historical development of migration policies in Libya, affected sub-Saharan migrants during the 20II Libyan conflict. Further, it discusses Bourdieu's concept of symbolic violence in relation to media representations of sub-Saharan and others' masculinities during the war in Libya. Finally, the study analyses the findings on sub-Saharan migrant masculinities as represented in three mainstream online news media: $A l$ Jazeera, The New York Times, and The Guardian. These media were selected because they address an international audience and have been influential actors in conveying specific understandings of the events during the war (Leudar/Marsland/Nekvapil 2004). To conclude, we present some reflections on the relevance of intersectionality to analysing media characterization of various vulnerable groups, discussing the importance of uncovering media's symbolic forms of violence within the claim for more comprehensive, egalitarian, and bottom-up understandings of human security. Some reflections on the practice of journalism and migration policies are also presented. In particular, the Libyan case raises important concerns in terms of the regulation of human mobility and the guidance and practice of Responsibility to Protect.

\subsection{Understanding Masculinities Through the Lens of Intersectionality}

The concept of intersectionality, since its emergence within black and third world feminist movements in the I970s and its academic re-elaboration from the late 1980 into the present, has inspired a comprehen- 
sive body of literature that focuses on multiple and cross-cutting forms and practices of exclusion, discrimination, and oppression (Bürkner 20I2). A main contribution in this field was made by Crenshaw in 1989, who coined the term intersectionality to address black women's experiences of domestic violence at the intersection of race and gender at different levels, a neglected juncture between different systems of oppression. Her approach allows an important distinction between the inequalities constituted by structural variables, e.g. to be poor, black, and male, and by political factors, e.g. cultural variables and social relations according to political agendas (Walby/Amstrong/Strid 20I2). The lens of intersectionality reveals how subjects are positioned and constituted by mutual shaping and constitution of intertwined context-specific structural conditions, discourses, and social practices (Yuval-Davis 2006; Walby/Amstrong/ Strid 20I2). These social practices are understood as context-based arrangements articulating overlays of oppressions linked to the distribution of locations and resources in society around different categories such as gender, ethnicity, and class, and at different levels such as structures, representations, or identity construction (Bürkner 20I2). Within this framework, the understanding of contextual elements avoids essentialism and generalizations that do not reflect the intersectionality of various categories.

Crenshaw (I99I) delineates three levels of intersectionality: structural, political, and representational. Structural intersectionality refers to the production of disempowered locations generated by intersecting structural patterns of subordination. In the case of black women addressed by the author, the junction of race and gender make their experience different from that of white women or black men. Political intersectionality speaks of clashes in the political agendas of different groups performing advocacy around particular features of marginal sectors and the imperatives that the marginal subjects are facing. For instance, the situation of black women is often ignored by the political agendas of both anti-racist and feminist groups, who have marginalized the specific circumstances of subordination of women of colour. Finally, representational intersectionality is linked to the construction of subjects' identities in popular culture. One example would be constructions of black men as agents of sexual violence against white communities, which become their fixed potential victim (Crenshaw I99I).

Crenshaw's frame contributes to debates on the potential of the concept of intersectionality for analysing the conditions of different social groups, by grasp- ing the complexity of factors involved in producing vulnerability and differentiated experiences of access to a life with dignity and safety. This angle on intersectionality can enable a more integral examination of the normative frame of human security, both in terms of deconstructing dominant notions and advancing a people-centred perspective. It is consistent with feminist approaches to human security that have highlighted the importance of acknowledging the differences masked by the term 'human' when addressing the politics of multiple overlapping social relations of power when engaged in the construction of the subjects (Hudson 2005). In this sense, the concept of intersectionality from Crenshaw's perspective contributes to enriching the paradigm of human security, because it facilitates the identification of multidimensional aspects and cross-cutting factors that condition a person's life. In the migrants' case, it is also applicable to an analysis of access to safe spaces and life with dignity, in terms of both an absence of direct threats as well as the conditions required for a better quality of life within a peaceful environment.

The case of sub-Saharan migrants during the Libyan conflict reflects an experience of the notion of 'triple jeopardy' used by feminist movements, meaning the oppression generated by simultaneous and interconnected patterns of oppression proceeding from the systems of racism, imperial capitalism, and sexism (Aguilar 20I2). The location of sub-Saharan migrants at the bottom of Libyan society as well as their vulnerability during the war appear linked to racialized, classed, and gendered constructions of their identity. These constructions are not fixed and their dynamics are to a large extent defined by contextual factors. They shift in the Libyan political system, moving from an understanding of black migrant workers as a necessary recruited labour force to economic burdens to deport. These changes in the construction of migrants' identity make their lives precarious, reinforcing their subordination, in a continuum along the structural and representational levels proposed by Crenshaw (199I). For this study, we focus on the representational level, where media play an important role in reinforcing or transforming the contents of those social constructions. An intersectional analysis of media representation will therefore result in a valuable tool for deconstructing how certain subjects are included in the ideas of security advanced by media. In this sense, the 'triple jeopardy' location of sub-Saharan migrants as well as their representations in media become highly influential factors in the achievement of their human security as media participate in 
establishing the frame of the debate on mechanism of protection.

Since, in the Libyan conflict, skin colour was a factor relevant to migrants' vulnerability, we are interested in race. Race is here understood as a constructed differentiation of people who are grouped around 'exclusionary/inclusionary boundaries' according to phenotypic features (Yuval-Davis 2006: 20I). Racial differences have been also used to construct and justify ideas of superiority, discrimination, and exploitation, which become normalized within society (Gopalkrishnan/Babacan 2007). Racial social hierarchies have deep historical roots, and they have not always been rationally constructed nor consciously identified. However, in conflict situations it is common to find that the link between race and ethnicity is an important habitual strategy of representation used by media to construct the 'good' and 'bad' actors. Further, media's selective reference to actors and events in racial terms raises or lowers the visibility of victims and perpetrators (Zarkov 20II). Inside this process, the role of media in perpetuating 'stereotypical images' could undermine the security of vulnerable groups because these 'symbolic tools' can influence practices dealing with the protection of civilians (Carpenter 2005).

In the case of Libya, a 'rentier' state with a small population extremely dependent on a foreign workforce, sub-Saharan migrants have usually been placed at the bottom of social hierarchies, becoming scapegoats for societal issues while performing jobs that are unwanted by the local population under exploitative conditions. Therefore, to understand migrants' vulnerability it is relevant to reflect on the topic of class, because class is a form of social boundary "grounded in relation to the economic processes of production and consumption" (Yuval-Davis 2006: 20I). In addition, class variables generate different forms of inequality and therefore are relevant to understanding marginalized groups and masculinities. In conflict situations class is a key aspect linked to risk because class determines the possibility of access to livelihood resources, and is therefore a crucial element in guaranteeing access to security. At the representational level, class divisions are usually normalized and migrants have become naturalized as part of the lower classes, so that selective access to protection is justified.

As mentioned earlier, gender is also a main aspect of interest for this study because its analysis allows the recognition of power relations established between and within groups of men and women, in the frame of societal structures that broaden or limit their op- portunities in differentiated forms. Gender is here understood as a "mode of discourse that relates to groups of subjects whose social roles are defined according to constructed [sexual] differences" (YuvalDavis 2006: 20I). This analysis helps us in conflict situations to appreciate the dissimilarities in terms of gendered participation in and, the differentiated impact of violence on women and men (Lorentzen/ Turpin 1998). Further, gender analysis uncovers additional understandings of media representations of how male/female migrants deal with and should access protection and security. For example, representations of civilian men in wars usually entail forced participation in violence or involuntary-compulsory exile from their community. This aspect of analysis is particularly relevant to the Libyan case, where most migrants are male. ${ }^{4}$ Moreover, centring the analysis on men makes it possible to identify how masculine characteristics and values of physical force, bravery, and honour are associated with the role of different actors and their particular gendered involvement in conflicts. This is not to say that manhood and masculinity are homogeneous categories: they intersect and interact within various social relations of power embedded in media representations. By adopting the intersection of race, class, and masculinities within the conditions of being sub-Saharan migrant workers as the main focus of analysis, we aim to understand how different masculinities are set in hierarchies, defining both priorities and positions from which to access protection and security. To understand these hierarchies, it is useful to begin with Connell (2005), who defines representations of masculinities as "symbolic processes of configuring practices" that transform gender relations over time. Within these processes, different types of masculinities can be identified: hegemonic, complicit, and subordinated (Connell 2005: 72).

Hegemonic masculinity comprises a set of values associated with the socially idealized model of manhood, implies dominance over other forms of masculinity, and shapes the organization of social and symbolic processes because of its links with institutional power (Connell 2005). It tends in international media representations - which often identify global values and norms with mainstream Western ones - to be associated with a secular, independent, and well-educated Western white bourgeois man, who is able to

4 Surveys of returnees during the Libyan war suggest the vast majority (over 95 per cent) are male and young (20 to 40 years) sub-Saharan migrants as well as Egyptians, Tunisians, and Bangladeshis (IOM 20I2). 
properly participate in wars to protect the nation and its ideals (Das 2008; Foster 2007; Carrigan/Connell/ Lee I985; Mohanty I99I; Connell 2005). Currently, hegemonic masculinity tends to be considered as not marked by aggressiveness (which in a conflict context is linked with modern warfare as the 'civilized' exercise of violence through the "mediation of law and technology" (Das 2008: 286)), but as rule-bound and rational among the relevant 'heroic' virtues.

Complicit masculinities refers to a type of manhood that, even if lacking some of the qualities and standards of hegemonic masculinity, still benefits from it and sustains the same hegemonic project (Connell 2005). From this logic complicit masculinities gain recognition in the masculine arena and achieve better power status for negotiation and broader opportunities for their interests. Within a warfare situation, this is the case for men who maybe do not fulfil all characteristics (such as race, class, knowledge, technology, or rationality) associated with the West, but who embody "the image of idealized masculinity through which they imagine themselves as participating in a universal worldwide military culture" (Das 2008: 288).

Finally, subordinated masculinities are the constructed sets "symbolically expelled from hegemonic masculinity" (Connell 2005: 78), which therefore lack legitimacy and whose characteristics tend to be blurred with feminine ones. This category is usually assembled as fragile, fearful, disgraceful, poorly educated, and therefore disempowered to act in negotiation or to control affairs. Within conflict, subordinated masculinities are usually presented as lacking any heroic virtue such as courage or capacity for selfsacrifice. Furthermore they are effeminate through references of fear, fragility, and dependence, and sometimes exposed within shameful situations to confinement, torture, or even sexual violence (Das 2008; Zarkov 20II).

In addition to these three types of masculinity, Connell (2005) introduced the category of marginalized masculinities, related to a more complex set of masculine hierarchies in which social differentiations based on gender intersect with other features directly associated with race, class, and so on. Marginalized masculinities embody different symbolic roles which are not just excluded from but antithetical to hegemonic masculinities. Within conflicts, for example, marginalized masculinities would include behaviour seen as savage and under the control of visceral passions. Their irrational characters lead them to inherently nihilistic forms of violence. Moreover, they are often represented as feminized in order to produce a humiliation of their manhood (Das 2008).

\subsection{The Production of Vulnerabilities and Instrumentalization of Migrants in Libyan Regulatory Migration Regimes}

In Libya's territory, migrants are a significant presence: they account for between eleven and twenty-five per cent of the population according to different figures, representing around 2.5 million foreign nationals in the country before 2OII (IOM 20I2). This figure includes from I to I.5 million sub-Saharan Africans, mainly from Niger, Chad, Mali, Nigeria, and Ghana (CARIM 20II; IOM 20I2). During the uprising and the conflict in Libya in 2OII, these groups suffered repeated experiences of violence, which strongly evidenced the conditions of vulnerability and life-threatening conditions lived by sub-Saharans staying in or transiting through Libya.

The International Organization for Migration (IOM) claims that this conflict has caused the worst migration emergency in the region since the first Gulf War. About 790000 migrants and their families crossed borders and concurrently a consistently high but indefinite number of migrants were caught in a situation of involuntary immobility, exposed to the violence of the war, stranded in overcrowded transit areas and camps, and obliged to use unsafe escape routes. Sub-Saharan Africans constituted a large part of this group, which was not in a position to be evacuated from the country (IOM 20I2; IMI 2OII; CARIM 2OII).

A number of historical preconditions gave rise to sub-Saharan Africans' vulnerability during the Libyan war in 20II, including most importantly the historical regulatory regime of migratory movements. In fact, changing and sometimes contradictory migration policies have made migrants' conditions in Libya precarious. This particularly affected sub-Saharan Africans, who have come to inhabit the most vulnerable positions in Libyan society, from which access to legal protection and economic resources is limited. Shifts in migration policies have been employed to cope with internal economic and political needs and used to satisfy the requirements of the international alliances established at each time. In particular, Libya's profile as a 'rentier' state meant that it both needed to attract an immigrant workforce and was exposed to the volatility of oil prices. The latter in particular led to periods 
of unemployment during which the presence of migrants was seen as a burden. Furthermore, in its shifting political alliances with Arab, African, and European countries, the Libyan state saw advantages in instrumentalizing the presence of migrants as political leverage in international diplomacy, prioritizing its raison d'état over the security of migrants.

Historically, transnational mass migration to Libya started in the early I960s with the discovery of energy resources in 1959 and the consequent establishment of large modernization programmes, which stimulated a high demand for a low-skilled labour force. Given that the Libyan population was small, large numbers of workers from neighbouring countries were recruited and Libya begun to rely heavily on immigrants for its economic development (Brachet 20II; De Haas 2008; IOM 20I2). This trend continued until the r 980 s, when the collapse of oil prices and the pressure of international embargoes ${ }^{5}$ made the country enter a period of recession. In an attempt to curb unemployment, Libya reduced, through mass deportations, the numbers of migrant workers in the country (Altunisik 1996). Given their presence in Libya at that time, these deportations disproportionately affected sub-Saharans, ${ }^{6}$ with a consequent reinforcement of their status as the most marginal migrants in the country. At the beginning of the 2000s, Libya faced an economic downturn and again used migrants as a scapegoat for societal problems (Huliaras 200I; Paoletti 20II; IMI 20II). Particularly emblematic of this second trend were the deportations following the clashes between Libyan and sub-Saharan workers in 2000 that had led to the killing of hundreds of migrants (Johnson 2000). In this case, state authorities did not pro-

5 During the I970s and I980s Gaddafi pursued an antiWestern imperialist policy, financially supporting insurgencies and radical governments in different parts of the world, including sub-Saharan Africa. During those years, Libya was accused by the West of supporting international terrorism. In response to the country's conduct in international affairs, the United States set up an oil blockade in 1982, the European Union established arms restrictions in 1986, and the UN imposed an air and arms embargo in 1992 (Ronzitti 2009).

6 Migrants from the sub-Saharan region represented nine per cent of the total migrant population in Libya in 1984 (Paoletti 20II). However, when oil revenues decreased in 1985, Tripoli expelled or laid off more than I00000 workers from Mali, Mauritania, and Niger in response to an economic crisis (Huliaras 200I). In the same year, 80000 Tunisians and Egyptians were deported in a general context where Libya accused Tunisia and Egypt of being pro-US (De Haas 2008). tect the sub-Saharans. On the contrary, responding to the hardening of anti-immigrant sentiments, more restrictive immigration policies were introduced and mass expulsions organized. This, together with arbitrary police treatment reserved for sub-Saharan migrants, increased the vulnerability of the wider black population (De Haas 2008).

Since coming to power in 1969, Gaddafi took a very pragmatic approach in his external policy, modifying Libya's alliances in response to transformations in the political and economic international environment (Paoletti 20II). A common trend until the end of the I990s was a strong anti-Western stance. At the beginning of the Gaddafi regime, Libya embraced Nasser's pan-Arabism (Huliaras 200I). As part of this agenda, preferential treatment for Arab migrants was given by, for example, facilitating access to Libyan citizenship and to other rights (Global Detention Project 2009; CARIM 20II). This established an unfavourable context for sub-Saharan Africans in terms of legal protection, with most able to access only the lowest-paid and least-protected jobs, making them easily exploitable and relatively more exposed to arbitrary police treatment (De Haas 2008). Beginning in the 1990s, Libya had to face the lack of support from Arab countries in the face of a UN embargo, and started to pursue a pan-African policy. Among the leverages employed by Libya to strengthen this new alliance, instrumental management of migrants took a substantial role. Thus a policy of threatening and carrying out deportations was later reversed into an open-door policy towards sub-Saharan nationals, to show Libya's commitment to reinforce ties with African countries. More precisely, the I990s saw the adoption of legal regulations to end visa requirements for sub-Saharan Africans: Libya thus became a major destination for migrants from West Africa and the Horn of Africa (CARIM 2OII).

Another major change in Gaddafi's international agenda came with his alignment with Europe at the beginning of the 2000s. This shift came about in relation to Libya's intention to regain international respectability, lift the embargo, and attract direct foreign investment. European interests in externalizing 'border control' to neighbouring countries also explain this $\operatorname{shift}^{7}$ (Paoletti 20II). As a result, Libya positioned itself as an EU partner in the governing of migratory movements by firstly reviving Italian-Libyan colonial ties and later by cooperating with the European Union. Among the main agreements it is worth remembering the 2003 operational pact, allowing Italy to sponsor the construction of detention camps 
for undocumented migrants in Libya; Italian financing of Libyan police training for border surveillance, border control equipment, and deportations of migrants from Libya to their countries of origin since 2004; and the 2008 Friendship, Partnership and Cooperation Treaty that sanctioned intense cooperation in different sectors and introduced new and contested measures such as pushing back practices in violation of the 'principle of non-refoulement' (Ronzitti 2009; Kumar 20II). This collaboration securitized migration, following the EU tendency to conflate crime, terrorism, and migratory movement. This reduced access to legal protection and the absence of any pressure on Libya to ensure the protection of refugees made the condition of its migrant workers and asylum seekers from sub-Saharan Africa even more precarious (Global Detention Project 2009; Kumar 20II). Thus both economic and geopolitical peculiarities of Libyan history led to the instrumentalization of migrants as political leverage.

The result of the cooperation between the EU and Libya is a good example of how instrumental regulation of migratory movements affected the security of migrants in Libya. In fact, this new international policy on sub-Saharan migrants resulted not only in tighter border controls and an expanded detention infrastructure but also promoted two further reforms reducing migrant security. In 2004, harsher penalties, heavy fines, and up to twenty years' imprisonment for crossing borders without the required travel documents were established (Global Detention Project 2009). In 2007, open-door policies were ended and visas for both Arabs and Africans became obligatory. At

7 At the end of the I990s and beginning of the 2000 s the EU increasingly framed Libya as a strategic territory for the movements of people through the Saharan and Mediterranean regions, despite the fact that the transSaharan space has been traditionally crossed by people in movement (Blanchet 20II). On the one hand, economic downturns and regional conflicts increased migration flows in the trans-Saharan space and tight controls on other parts of the Mediterranean coast, in particular the Straits of Gibraltar, resulted in a partial reorientation of migratory movements with migrants trying to reach Europe from Libya. On the other, Libya remained mainly a destination country, but its description as a transit area has been used as political leverage for Gaddafi to negotiate with European governments (De Haas 2008; Branchet 20II; Paoletti 20II).

8 The principle of non-refoulement refers to "the obligation of states not to forcibly return people to countries where they face persecution or serious harm" (UNHCR 2OII). the same time, changes concerning residence and labour permits suddenly turned an unknown number of immigrants into irregulars (CARIM 2OII). In this context, racist insults ${ }^{9}$ and attacks, inequitable police treatment, thefts, and failure to be paid after completing work were increasingly reported by sub-Saharan Africans (Hamood 2008). These trends highlight how the processes of migration management engender conditions of vulnerability and open spaces for diffused legitimate violence against the migrant population.

In sum, marginalization of migrants in Libyan society, differential treatment for racially differentiated groups of migrants, contradictory political agendas, economic interests, and the processes of EU externalization of migration controls all laid the basis for the reproduction and escalation of violence against subSaharans during the 2OII conflict. This trend was evident even at the beginning of the protests: in February 20II, rumours and statements regarding Gaddafi's hiring of mercenaries from sub-Saharan Africa resulted in rebel forces attacking black people, both migrants from sub-Saharan Africa and black Libyans. At the same time, sub-Saharans and blacks feared both rebel attacks and being drafted into Gaddafi's army (Del Grande 20IIc). Their situation did not reach the attention of the international community, while stories of black mercenaries did. The international community did however uphold the principles of Responsibility to Protect and human security as its underlying framework with the declared intent of avoiding mass violence and guaranteeing the safety of civilians (ICRtoP 20I2). In March 20II, UN resolutions 1970 and 1973 first imposed an arms embargo and a travel ban on the Gaddafi family and members of government, froze the assets of the Gaddafi family, and referred the situation to the International Criminal Court for investigation, and later sanctioned a no-fly zone to protect Libyan civilians, and authorized Member States, in cooperation with the Security Council, to take "all necessary measures [...] to protect civilians and civilian populated areas under threat" (UN 20II). ${ }^{10}$

This lack of attention to the position of sub-Saharans was evident again in the process of evacuation organized by the international community. While Libyans and groups of migrants fled the country in large

9 It is common in Libya to refer to a black person with the derogatory and depreciatory term of ' $a b d$ ', in English 'slave' (Hamood 2008: 40).

10 See Press Release from United Nations, Security Council 10200-6498 $8^{\text {th }}$ Meeting; at: <http://www.un.org/ News/Press/docs/20II/scIO200.doc.htm>. 
numbers, in most cases sub-Saharan migrants did not find a safe escape route and were involuntarily immobilized in Libya without the basic conditions for a life with dignity (IMI 20II; UNCHR 20IIa). Sub-Saharan migrants who reached the Tunisian, Egyptian, and sometimes the Chadian borders requested refugee status but remained stuck in transit camps (UNCHR 20IIa). Even in the absence of precise data, ${ }^{11}$ it is possible to state that great numbers of civilians who escaped by sea died in the attempt (Forte 20IIa). Those who did manage to reach the coasts of Italy and Malta found themselves in the detention-deportation system of the European Union regime of migration control (Del Grande 20IIa). In particular, the measures provided by the Italian state under the framework of an emergency Reception National Plan ${ }^{12}$ have been criticized for holding asylum seekers under inhumane conditions, examining asylum applications with extreme slowness, and denying refugee status to most non-Libyan nationals on the basis that they are in a position to return to their home country (Garelli/ Tazzioli 20II; Vassallo Paleologo 20II). Concurrently, internal displacement persisted, and violence against blacks did not cease (Koser 20II; UNCHR 20IIa/ b). ${ }^{13}$ Furthermore, the war in Libya has had negative consequences for all migrants in terms of employment and income, increasing their vulnerability by reducing their access to food and health care. This material vulnerability is reflected in migrants' returning to their home countries, where they face a lack of economic resources and their families are confronted by the absence of remittances (IMI 20II; IMO 20I2).

A set of contradictory interests have crossed the discourses and practices of the international community during this conflict, prioritizing migration control over concerns about the security of migrants remain-

11 According to UNHCR, "More than I500 drown or go missing trying to cross the Mediterranean in 20II" (UNHCR 20I2); at <http://www.unhcr.org/4F2803949. html>.

12 To consult the plan see at: <http://www.protezionecivile. gov.it/resources/cms/documents/Piano_migranti.pdf>.

13 In a press release of 22 August 20II, Antonio Gutterres, High Commissioner for Refugees, is quoted as follows: "We have seen at earlier stages in this crisis that such people, Africans especially, can be particularly vulnerable to hostility or acts of vengeance" (UNCHR 20IIa). Addtionally, at the time of writing [August 20I2], three sub-Saharan asylum seekers were killed by the Libyan military during a protest in a detention centre for refugee applicants to the east of Tripoli. See at: <http:// habeshia.blogspot.it/20I2/o8/a-massacre-of-asylum-seekers-in.html> (30 August 20I2). ing in Libya. In fact, even where external intervention was planned to guarantee civilian safety, NATO forces did not act consistently to protect sub-Saharan migrants and refugees within and outside Libya. Minimal evacuations and actions were organized to address the particular dimensions of risks and threats to the sub-Saharan population. On the contrary, European countries saw any movements towards their territories as an 'incoming invasion' ${ }^{14}$ and failed to act in favour of migrants' security, something particularly needed for this group. Emblematic of this attitude has been the Atlantic Alliance's refusal to help migrants' drifting boats at the end of March and at the beginning of August, which caused dozens of deaths (Del Grande 2OI2b). Even as substantial resources were allocated for humanitarian aid and some emergency evacuations were organized by UN agencies later in the war, the protection of sub-Saharans' lives was not a clear priority. Instead, precedence seemed to be given to the control of migratory movements. Indicative of this is a proposition by the Italian government in June 2OII that solicited NATO to block migrants' ships and return them to the southern shore of the Mediterranean, which clashed with Italian and European discourses and practices concerning humanitarian aid and support (Migreurop 20II). In short, the EU understanding of sub-Saharans as a potential threat increased migrant vulnerability to violence and life-threatening circumstances.

\subsection{Symbolic Violence and Media Representations of the Libyan Conflict}

To confront the violence lived by sub-Saharan migrants in Libya and the limited political will as well as the action displayed by the international community to guarantee their security, it is relevant to show how the identities of sub-Saharan migrants have been constructed within the media. As the principal source of

14 De Haas (20I2) has noted that both European politicians and media have repeatedly referred to an incoming invasion. For example the Italian Minister of Foreign Affairs, Franco Frattini, has talked about "an invasion of two to three hundred thousands of migrants", while the Italian Interior Minister has referred to a "human tsunami”. See at: <http://www.corriere.it/esteri/11_feb braio_22/evacuazione-italiani-libia_I3FI56FC-3E78-IIe0-a0 25-F4888ad76c86.shtml>; <http://ricerca.repubblica.it/ repubblica/archivio/repubblica/20II/O4/2I/la-polemica. html> (20 June 20I2). 
information on which global public opinion relies, media representations produce meanings and relations that make sense of the violence they narrate and, consequently, suggest appropriate behaviour and conduct (Titscher 2000). Representations of different actors in war contexts, through specific narratives, framings, and categories, are key elements through which media implicitly or explicitly advocate, construct, or justify modes of action (Leudar/Marsland/ Nekvapil 2004). It follows that how sub-Saharan migrants have been approached will be strongly connected to media representations of the Libyan conflict as well as of its causes, responsibilities and contributing factors, and the possible solutions to the migration crises that it entailed.

As mentioned earlier, intersectional analysis can illuminate how the positioning and constitution of subjects and groups in society are constructed at different levels and through different and interrelated social discourses and practices. Since social discourse is at a macro-level filtered through and by media, our focus on media aims to address the level of symbolic representations circulating in societies. Such representations have been defined by Bürkner (20I2), following Crenshaw (I99I), as part of the meso-dimension of intersectionality, revealing interdependencies among different societal structures (macro-dimension) and processes of identity construction (micro-dimension). However, for our purposes, only the interconnections between symbolic representations and structures need to be addressed. Thus here intersectional analysis is employed to enable us to comprehend how media representations of sub-Saharan migrants during the 20II Libyan war suggested why and how migrant security should be addressed and who should address it, and placed this within a context of transnational migration management. In addition, this analysis specifically focuses on how the intersections of the categories of masculinities, race, and class enable a deeper comprehension of media representations and their role in conflict, as well as how this affects other actors.

Finally, the analysis reveals suggestions conveyed by such representations about how to address migrants' access to security in conflict, expressed in many cases through categorization ${ }^{15}$ strategies. For example, when sub-Saharans are defined as 'mercenaries' - in journalists' reports 'according to rumours' ${ }^{16}$ -

15 'Mercenaries', 'poor desperate', 'helpless', and 'trapped' are some of the most frequent terms found in the news media in reference to the sub-Saharan population in Libya. some media implicitly argue for the need to control and securitize 'these dangerous' subjects, instead of arguing for their protection. This type of categorization also supports the rebels' call for an external intervention by the international community in order to pacify the situation. ${ }^{17}$ In addition, when migrants are described as 'poor' and 'desperately hoping' to reach Europe, the implicit message argues for the importance of limiting arrivals of sub-Saharans on European coasts, as they might constitute a danger for the local population because of their condition of despair. ${ }^{18}$

Media representations of sub-Saharans during the coverage of the Libyan war as well as their implications for migrants' security have been debated both in academia and other circles. The international media's silence about the lynchings of both sub-Saharan migrants and black Libyans in the first stage ${ }^{19}$ of the conflict has been criticized as diminishing the dignity and worthiness of these lives (Chatora 20II; Marshall 20II; Forte 20IIa/b). Further, media emphasis on the rebels' claims about sub-Saharan mercenaries may, it has being argued, have fuelled these events, firstly by corroborating unconfirmed information and secondly by making violence against the black population in Libya acceptable by framing sub-Saharan migrants as dangerous subjects. These media representations have been seen as reinforcing the urgent claims for external support to the rebellion, later concretized with the NATO humanitarian intervention. Overall, media also have been thought to support the narrative of a united Arab Libyan people committed to fighting against an isolated Gaddafi, supporting calls for an international intervention (Forte 20IIa/b; Marshall 20II). International media have also been criticized for constructing the fear of an invasion of Europe by overemphasizing sub-Saharans' movements from Libya to Europe across the Mediterranean, without questioning the dimension of the real numbers ${ }^{20}$ or the lack of protection experienced by migrants (De Haas 20I2).

16 See Forte, 20II "The top ten myths in the war against Libya"; at: <http://pambazuka.org/en/category/features/77439>.

17 See for example article (I) analyzed from the New York Times.

18 See for example article (2) analyzed from the New York Times and articles (3) and (4) from Al Jazeera.

19 We consider the first stage to have lasted from February to July 2011, when violence against sub-Saharan Africans was invisibilized. It was not until August, with the publication of human rights and other international studies, that media started to mention in a more visible way the lychings of sub-Saharan Africans. 
However, research exploring sub-Saharan racialization has failed to intersect such understanding with gendered social practices. Thus this study, conducted on the media representation of sub-Saharan migrant masculinities during the Libyan conflict, may be one of the first. It shows that the construction of their identity in the news has strongly relied on ideas about maleness: as presented by different studies, migration, conflict, and state ${ }^{21}$ are highly gendered processes and institutions whose meanings media contribute to constructing. For example, sub-Saharan men were often framed as potentially active actors in the conflict, whether as mercenaries or as objects of forced enlistment: ${ }^{22}$ their participation or exclusion from the war as well as their sense of loyalty were part of the construction of their maleness. The same could be said about the media representation of 'migrants' in Libya as an exclusively male category. These elements influenced their positioning at the bottom of different hierarchies of masculinities, at the same time that it had important repercussions for the framing of their vulnerability and the possible understanding of their human security. This shows the relevance of considering masculinities of migrants in the 20II Libyan conflict. Additionally, as some studies in racist violence suggested, masculinity is relevant "since the perpetrators of most racial attacks are young men attacking other young men" (Anthias 2007: I4).

Thus, media representations constitute and position subjects, suggesting, justifying, or promoting particular behaviours and actions (Leudar/Marsland/ Nekvapil 2004). In so doing, such representations may exercise forms of symbolic violence by legitimizing as valid certain models and norms. As Bourdieu suggests, symbolic violence is a "hidden [...] gentle, invisible form of violence, which is never recognized as such" (Bourdieu 1977: 192). It assigns characteristics to social groups that make acceptable and even natural their subordinated or privileged location, while questioning these positions is made harder precisely because such normalization is not openly exposed (Bourdieu 1977). Additionally, as socio-psychological studies have shown, the symbolic violence intrinsic to stereotypes and prejudices is difficult to convert with-

20 It is estimated that just 24465 persons ( 3.9 per cent) of the overall 790000 migrants and their families fleeing Libya arrived in Italy and Malta (IMO 20I2).

21 Charlotte Hopper (2008) is one of the few authors who elaborate on the links between masculinities and state, particularly in the book Manly States: Masculinities, International Relations and Gender Politics.

22 See Al Jazeera (2), (3), (6), and (9). out detailed and deep analytical reading, because much of the content and subtle assumptions of such stereotypes and prejudices can be beyond rational awareness (APS 1997). Therefore it is important to reflect on dominant discourses, observing the elements and actors included, the ways in which they are represented, and the consequences of these representational strategies for debates about security. Representation may thus justify subordination, discrimination, exclusion, and marginalization of subjects who do not meet established norms. In Fraser's terms, "representation [is] the defining issue of the political", establishing who is subject to what security (Fraser 2009: I8).

\subsection{Visibilizing the Role of Media in the Creation of Human Insecurity: Information on the Libyan War 2011}

As the Libyan conflict became an international issue with the involvement of the so-called international community, this chapter uses three international mainstream media that aimed to address a global public. All three have online editions, generally free and more accessible, and in this chapter we consider a selected number of news and opinion articles covering the period of the conflict from the beginning of the protests in February 20II to the death of Gaddafi in October 20II. The media selected are The New York Times (NYT), The Guardian (TG), and Al Jazeera English (AJ). The first is a US national daily newspaper and its online edition is one of the most viewed in the world, despite the fact that since $20 \mathrm{II}$ free online access to its archive has been limited. Its political line is considered centrist, and it is owned and financially controlled by a corporation. The Guardian is a British national daily newspaper, also with an international online multimedia presence. Its editorial line tends towards centre-left liberalism and its position on migration issues tends to be considered quite progressive. Its contents and archives are freely available online. Funded by a charitable foundation, The Guardian claims to be characterized by political independence. Al Jazeera English is a news channel broadcasting from Doha and London. It aims to provide a liberal perspective from the Global South on global issues, specifically conveying a Middle Eastern point of view. It has been criticized for adopting both a pro- and an anti-Western bias, and also for reporting in a crude style described as a 'negative trend'. ${ }^{23}$ Financially, $A l$ 
Jazeera depends mostly on Qatari government subsidies.

In addition to their wide audience, the criteria applied for selecting these media have been their recognition at the international level and the different perspectives they are believed to offer in terms of political and geographical standpoints. For the selection of articles, at first we conducted a research exercise into archives to identify news dedicated to the Libyan conflict and focusing on sub-Saharan Africans. Second, from this base sample we chose specific articles to analyse - news and opinion texts - connected to relevant events ${ }^{24}$ during the conflict which saw the involvement of sub-Saharan migrants; in doing so, we attempted to balance the selection of articles to cover the period mentioned. After a detailed examination of thirty selected articles, ${ }^{25}$ the analysis demonstrated homogeneous patterns in terms of the representation of masculinities among all selected articles - notwithstanding the different sensibilities and ideological inclinations of both media and journalists. In this way, we arrived at thematic/data saturation as the purpose of our sample was "not to count opinions [...] but to explore the range of [...] different representations" of subjects (O’Reilly/Parker 2OI2: 3).

The analysis procedure first focused on identifying the main narratives presented in the material analysed, specifically the assumptions and values produced in the text in the way characters, actions, and events relate to each other (Titscher 2000). These were searched for clues to understand how media suggest addressing the security of sub-Saharan migrants in the conflict. This analysis was further enriched by reasoning about the framing of the articles analysed, especially the aspects of reality made more salient or excluded so as to convey a particular understanding of the events narrated (Zarkov 20II). Finally, categorization analysis allowed for an understanding of how

23 Adjective used in a letter attributed to Mike Maples, director of the US Defense Intelligence Agency, in a wikileaks, at: <http://www.cablegatesearch.net/cable. php?id=06DOHA $37 \mathrm{I}>$ (May 20I2).

24 The relevant events considered have been: evacuations and spreading of rumours about sub-Saharan mercenaries at the beginning of the conflict (February and March 20II), sub-Saharans' boat voyages in the Mediterranean (April-August 20II), relevant battles in Misrata (May 20II) and Tripoli (August 20II), media acknowledgement of massacres of sub-Saharans (August and September 2011), death of Gaddafi (October 20II).

25 A complete list of the selected articles and their internet links is presented in table 13.3 below.
sub-Saharan migrants and their masculinities have been represented, and how these representations justify certain type of actions towards them (Leudar/ Marsland/Nekvapil 2004).

Within the articles considered, three main narratives related to the 20 II Libyan conflict have been identified through a reading of the text aimed at identifying 'topoi' or argumentations explaining the situation in which sub-Saharans found themselves in Libya (Reisigl/Wodak 200I). These refer to the revolution, migration crisis, and humanitarian intervention, with racism as a cross-cutting theme. They were not developed at the same time in all the articles analysed, but these implicitly supported each other and offered a general framework of interpretation for the events that the media provide an account for. Along this line, all three media offered common readings and perspectives and only a few differences or major tendencies can be noticed. Al Jazeera tended to provide more information regarding the context of Libya and the sequencing of events, acknowledging the complexity of its society. For instance it recognized differences in terms of ethnic/racial groups living in the country, acknowledging diversity in the Libyan population in terms of phenotypes. ${ }^{26}$ The Guardian was more inclined to present migrants as victims and claim the moral importance of addressing issues related to their security, consequently celebrating its role as an ethical agent. ${ }^{27}$ Finally, The New York Times distinguished itself by insistently essentializing

26 This is the case in the Al Jazeera article (2) where under the subtitle of dangerous racism, it is stated: "In the past, Gaddafi has oppressed both black Libyans and ethnic Arab Berbers in the western Nafusa Mountains. Last year, the regime lashed out against the Tabu tribe, darker-skinned Libyans who live in and around the towns of Sabha and Kufra near the Chad border." This information confirms once more that the black population belongs to diverse groups of black Libyans, instead of just sub-Saharan Africans.

27 In all pieces analysed from The Guardian, concern for sub-Saharan migrants is expressed, with a tendency to portray them as victims. In articles (3), (7), and (IO), the role of media as actors denouncing injustice and thus contributing to attracting attention to problems to be resolved is openly celebrated. No discussion of the frame which media adopts to foster their denunciations is offered. On the contrary, when it is recognised that journalists may have participated in falsely labelling subSaharans in Libya as mercenaries, article (IO) minimizes these errors, arguing that media have showed to be able to correct themselves, proving the reliability of their reports and interpretations. 
spaces of Africa, Libya, and Europe, thereby reducing the complexity of the processes described. ${ }^{28}$

At the outset of the analysis it is important to point out that the revolution ${ }^{29}$ is represented as a stage in a positive and necessary developmental process moving toward Western liberal democracy as a sort of end of history. That is, in the heart of the struggle for power between anti-government protesters and Gaddafi's loyalists, the former are represented as champions of democracy and human rights moving closer to the accomplishment of these values (AJ 2-96; NYT 2-5-9; TG 7-IO). Notwithstanding the military imbalance between the two groups, since the beginning of the protests the rebels' possibilities of success are exalted, while Gaddafi is constantly described as on the brink of defeat (AJ 5-6; NYT 1; TG I-9). A highly teleological vision is deployed, according to which Libya is seen as chasing the West and its ideals with the whole country's population united in supporting this effort (AJ 6-9; NYT I-5; TG 7-IO). A Western liberal democracy, a market-oriented economy, and modern social organization are represented as the best and more likely future, guaranteeing justice, freedom, and prosperity to 'all' those living in Libya. However, the rebels' approach to democracy is seen as incomplete because - despite their rhetoric of secularism, transparency, and rule of law - the opposition's commitment to Western values remains to be proven in the post-revolutionary period. This is presented in contrast with the long history of Western democratic experiences, which emerge as superior (AJ 2; NYT 2-3-5; TG 7).

Episodes of non-legitimate violence committed by the rebels were denoted as indicative of the limits of Libya's revolution: "Libya's spectacular revolution has been disgraced by racism" as titled by the Guardian at the end of August (TG, Io). ${ }^{30}$ However, in the media, the origin of such violence was identified as the weight of Gaddafi's inheritance, diminishing the opposition's responsibility (AJ 2-3-9; NYT 5; TG 2-3-4-6IO). The racist attacks against sub-Saharans in Libya

28 This tendency is particularly evident in articles (I), (2), and (3) from the NYT. In these cases Libya tends to be represented as a dangerous place, Europe is a stable and prosperous area, while sub-Saharan countries are characterised by poverty, corrupt governments, and stagnant economies.

29 It is important to notice that the understanding of revolution as a necessary step is one of the main narratives found in media, and it also became a justification for the conflict and its consequences.

30 See also articles (5), (9), and (Io) from NYT, and AJ (2). are emblematic of this story line: the root cause of this violence was identified as a long history of exploitation and discrimination against sub-Saharan migrants throughout Gaddafi's regime, in some way normalizing the spread of racism $^{31}$ in society. The weakness of the revolution was seen as proceeding from years of repression which have caused the absence of organized movements able to move beyond racist understandings of nationalism and construct an inclusive sense of belonging (TG Io). The violence of the repression ordered by Gaddafi was then presented as a multiplier of the racist tendencies of Libyan society: the brutal attacks of government loyalists obscured the protesters' capacity of judgement (AJ I; NYT 4; TG 3). This subtle message is particularly reinforced through the image of sub-Saharan Africans as mercenaries, which also explains the violence suffered by them (AJ I-6-7; NYT I-9-IO; TG I). Further, it was the war that - by impeding the implementation of a justice system - enabled a situation of diffused violence. The opposition was presented as having good intentions and Western sympathies, while the savage and cruel forces of Gaddafi worked to undermine the revolution as a hope for democracy (AJ 5-6; NYT i; TG 4-7-10).

The migration crisis was represented by media as fully the responsibility of Gaddafi (AJ I; NYT 5; TG 3). This is exemplified by another title: "Helping Libya's refugees is the better way to beat Gaddafi" (TG 7). Opposing and resisting a necessary change, the Colonel was generally seen as the principal subject to blame for the disastrous effects of the war. In particular, complex migratory movements and increased vulnerabilities that resulted from the conflict and affected all migrants in Libya (sub-Saharan or not) was understood as taking place due to Gaddafi's choices. He was seen as committed to 'creating' refugees by spreading violence within Libya and impeding rescue efforts; he was also presented as attempting to force sub-Saharan Africans in Libya to fight on his side or leave the country (AJ 2-3; NYT 3-4-5; TG 2-4-5--IO). Finally, he was portrayed as 'exploiting boat people' by facilitating their journey across the Mediterranean in order to frighten Europe with the possibility of massive arrivals of migrants (AJ 2; NYT 2-5; TG 4-7). To support such a reading of the crises, as noted earlier, media tended to diminish the responsibility of the rebel anti-Gaddafi forces with regard to migrants' security (AJ 2-3-7; NYT 4-5-9; TG 2-4-5-IO). In short, the media story was that as a result of a conflict desired by Gaddafi, migrants were obliged to expose them-

31 See AJ (2) and (6), and NYT (9). 
selves to very risky situations: internal displacements or perilous travels across the Mediterranean, carrying additional dangers and insecurities for sub-Saharan migrants previously living and working in Libya.

Movements of people were seen by media as carrying negative consequences not only for the migrants themselves, but for other actors too. For example, European states were represented as legitimately perceiving their coasts as 'invaded' and facing resentment towards migrants by their populations, widely supportive of anti-immigration stances (AJ 4; NYT 23; TG 5-8). The rightness of such positions was then justified by the idea that migrants, especially sub-Saharans, are untrustworthy and dangerous subjects for Europe (AJ 3; NYT 2-3). The media suggestion was that most, by entering Libya illegally, had proven themselves to be disrespectful of rules. Further, their desperate condition was seen as a factor that might cause further problems to European countries, as desperation leads to desperate and irrational behaviours (NYT 2-3). In addition, Tunisia and Egypt were other actors presented in some of the articles analysed as facing the problems of migratory movements. Notwithstanding their proven goodwill in helping migrants, the two North African states had to face exasperation from their own citizens for the problems caused by sub-Saharans in refugee camps who 'stupidly protested' about their situation without appreciating the efforts made by those countries (TG 6). As a consequence, the needs for border control, refugee camps, and organized management of migratory movements were implicitly presented as necessary and appropriate solutions for avoiding additional problems in destination countries and for migrants themselves (AJ 3-4; NYT 3-7; TG 6).

From these understandings of the conflict and migration crises, the humanitarian intervention was established by media as a necessity in order to save lives from the irrational violence of Gaddafi's forces. The international community was the actor charged with the responsibility of preventing fighting from escalating and alleviating suffering (AJ I-2-5-6-7-8; NYT I-2-34-7; TG I-3-5-7). However, even if the term 'international community' conventionally refers to the community of world states and UN organizations as supposedly super partes actors, in media it more often indicates just Western states and certain international agencies as high moral subjects committed to protect Others, beyond the principle of sovereignty (AJ I- 8 ; NYT I-2; TG I-2). Such selective use of the term establishes a hierarchy in which states like Egypt or Tunisia, though actively engaged in the organization of human- itarian support, are represented as less organized and proactive in the effort to save human lives (TG I-6). This contrasts with visions of Western states and UN agencies as endowed with the means and resources for assessing the situation and best planning any intervention. In this vision, they are courageous and generous agents ready to self-sacrifice, have great care for human lives, and have the capacity to act (AJ I-3; TG I-2).

When the international community fails to comply with these standards publicly, its accountability is established through different techniques. First, other responsibilities are identified and often these are not elements within the control of the so-called international community: for example, the weather or the bureaucratic system is seen as hampering rescue efforts in the Mediterranean (TG 2-4). Also, the irrationality of other actors can be used to explain the international community's failures: sub-Saharans in desperate situations would be inclined to not exercise clear judgement and to put their lives at risk, as when, trying to capture the attention of a rescue boat, they move to one side of their ship, causing it to capsize (TG 2). Moreover, NATO and EU states are pictured as self-reflexive and prone to take actions that will improve their tactics and strategies of intervention, for instance improving coordination efforts for evacuations and lifesaving missions at sea (NYT 5-7; TG 78:). Finally, media and other actors take the role of powerful watchdog, engaged to show the international community unforeseen problems and to envision possible solutions, as in the case of unanticipated migratory movements towards Europe or racist attacks on black Libyans and migrants in Libya (AJ 2-35-6; NYT 5; TG 5-7-IO). In this case, in addition to migrants' testimonies employed to confirm the information presented, many references to Western values of liberal democracy serve as guidelines for actions, completely legitimizing the actual organization of the world order and failing to address existing inequalities and imbalances (AJ 2-6-9; NYT 5; TG 7).

In a nutshell, media represented the Libyan conflict as a step in the country's process towards Western ideals and modernity; they show its migration crises as the result of irrational, cruel, and short-sighted policies by Gaddafi, and this implies that support for the management of migratory movements by Western interventions was necessary to achieve security, freedom, and the democratic principles of the international order. Direct and subtle associations in the articles analysed indicate strongly that media conveyed suggestions that reinforced mainstream international models while play-acting mobilizations for migrants' 
Table 13.1: Media narratives related to the 2011 Libyan conflict. Source: The authors.

\begin{tabular}{|c|c|}
\hline \multirow[t]{4}{*}{ Revolution } & $\begin{array}{l}\text { Stage in a developmental process directed towards a model of society based on liberal } \\
\text { democracy, free market, and other values presented as Western. }\end{array}$ \\
\hline & $\begin{array}{l}\text { Result of long years of Gaddafi's regime, which spread hate and enabled episodes of ille- } \\
\text { gitimate violence to take place (e.g. repression, racism, and violence against different eth- } \\
\text { nic groups). }\end{array}$ \\
\hline & $\begin{array}{l}\text { Contributes to demonstrating the backwardness of some countries and the superiority of } \\
\text { the West that does not need conflicts to provide freedom, stability, and prosperity. }\end{array}$ \\
\hline & $\begin{array}{l}\text { Event to support the process of democratization in other parts of the world through } \\
\text { Western institutions and organizations. }\end{array}$ \\
\hline \multirow[t]{3}{*}{ Migration crises } & $\begin{array}{l}\text { Result of Gaddafi's behaviour: he did not care about putting the life of migrants at risk in } \\
\text { Libya as his way of resisting a necessary change. }\end{array}$ \\
\hline & $\begin{array}{l}\text { Situation of danger for migrants themselves, but also for Europe and Libya's neighbour } \\
\text { countries. }\end{array}$ \\
\hline & $\begin{array}{l}\text { Situation to support an efficient and organized management of migratory movements as } \\
\text { a necessity for achieving security }\end{array}$ \\
\hline \multirow[t]{3}{*}{ Humanitarian intervention } & $\begin{array}{l}\text { Situation for the West to use its generosity, skills, and abundant resources to save the lives } \\
\text { of thousands of civilians. }\end{array}$ \\
\hline & $\begin{array}{l}\text { Event to support Libya's path towards liberal democracy, free markets, human rights prin- } \\
\text { ciples, etc. }\end{array}$ \\
\hline & Action through which the West establishes its accountability. \\
\hline
\end{tabular}

security. This reading of the events and processes described is reinforced through different strategies, including media's silences over certain elements. For example, the lack of mention of the civilians killed by the NATO intervention allowed a dichotomous vision of the conflict in which good and evil faced each other, making invisible those suffering and whose experience could not function to support such readings of the conflict. The superiority of Western democracies, in relation not only to the Gaddafi government but also to the incoming opposition, was made possible by excluding memories of past European colonization and the present reality of a legitimized racism against black Africans. The absence of any reflection on how EU migration control policies played a role in limiting sub-Saharan migrants' possibilities for safe evacuation contributed to a polarized comprehension of the situation, which is revealed in the silence surrounding the expulsions of asylum seekers from Europe. The lack of acknowledgement of Western geopolitical and economic interests also contributed to legitimizing and celebrating the NATO intervention. More examples could follow, but for the purposes of this study, our attention is now turned to the media categorization of sub-Saharan migrants.

Within media representations, different sets of masculine values can be distinguished, organized in hierarchies and associated with different social groups. The hegemonic model of masculinity is here linked to constructs of the international community as a neutral actor not directly involved in the conflict, but whose efforts aim at saving lives. In doing so, the international community displays skills related to rationality, expertise, moral strength, and determination, while being guided by heroic virtues related to courage, generosity, and capacity for self-sacrifice (AJ I-3-4-7; NYT IO; TG I-2-7-9). Further, the availability of means and resources not only represents the international community's capacity to feasibly respond to crises and conflicts, it also makes it possible to relate actors to different ideas of success (AJ 8; NYT I-2; TG I). As emerged from the narrative analysis, the term 'international community' often refers to only Western states and selected international agencies. From here it is easy to infer that the success associated with hegemonic masculinity in this case refers not only to the economic area, but is a manifestation of Western achievements in different fields, mainly connected to the model of the white race, professional education, aid workers, policymakers, entrepreneurs, or corporate managers. Media representation of hegemonic masculinity thus becomes involved in legitimizing a specific array of values and reproducing dominant social relations (Carrigan/Connell/LeeReviewed I985; Connell r998).

The complicit category of masculinity in the context of the Libyan war could be identified in the rebels, the opposition to Gaddafi. Anti-government 
forces, "former regime notables, businessmen and professionals as well as exiles" (TG IO), were in fact associated with certain values of hegemonic masculinity: proactivity and determination, advanced education, democracy, and the principles of the free market. However, the rebels distanced themselves from the international community's hegemonic model of masculinity by fighting a war using violence and by their lack of military technology and strategy (AJ 5-6; NYT 9). Because Gaddafi's opposition sought to engage in conflict rather than just employing its resources in the service of others - as Western masculinity is represented to do - they are seen as developmentally a step behind the international community (NYT 2-3-5; TG 7). Nonetheless, this behaviour is identified as a necessary act of courage. From this perspective, the rebels are allowed to receive support from the international community because they fulfil the majority of qualities of the hegemonic model of masculinity, including their concern for assisting and supporting those in need (NYT 4; TG 9). As a result, the values in media representations associated with the rebels' complicit masculinity work again to support hegemonic masculinity's values and the dominance of the rational, polite, and educated man moving within the frame of capitalist interests. An illustrative example is the start of one Al-Jazeera article: "Sporting a crisp well-tailored grey suit and pink tie, Harris Mohamed Zuwei looks more like an aspiring banker than a Libyan pro-democracy fighter who took a bullet for the cause" (AJ 6).

The subordinate model of masculinity is here embodied by Gaddafi, the 'mad dog' of the Middle East, as President Reagan defined him in the I980s. ${ }^{32} \mathrm{Me}$ dia portrayed the Colonel as a non-modern and irrational figure, whose cruel and unreasonable decisions had very serious and negative consequences for already marginalized subjects. ${ }^{33}$ Demonstrating a deficiency of clear judgement by choosing to oppose what is presented as an upcoming and inevitable change, Gaddafi and his loyalists put at risk the lives of the vulnerable and thus came to symbolize cowardice and the lack of any heroic virtue, "gangster[s] who hold foreigners at knifepoint in the Libyan streets" (NYT

32 See BBC News: "Profile: Muammar Gaddafi", 27 June 20II; at: <http://www.bbc.co.uk/news/world-africaI2488278>.

33 "Sins of the father, sins of the son" is a title of a news article in Al-Jazeera on 27 February 20II, where Gaddafi is accused of "exploitation of the plight of the African people” (AJ 9).
2). Egotistically attached to power, their behaviour is explained by media with reference to hysteria, associating this subordinate manhood with feminine features (TG 3 ). This type of masculinity is then banished from the hegemonic model, and lacks legitimacy in relation to the norms supported by the latter. However, this expulsion does not constitute a negation, as in fact Gaddafi is still represented as a subject endowed with agency: he does not simply react; on the contrary he is an extremely proactive agent. From this sense of initiative, his moral and ethical condemnations emerge and find justification (TG 7). Consequently, according to the logic of contraries, the hegemonic masculinity embodied by the Western international community is again reinforced by the media through the insistent message of its necessary action to control Gaddafi's 'erratic' performance (AJ 9).

Mainstream international media fixed images of sub-Saharan migrants through categories associated with ideas of passivity or dangerousness. The representations of sub-Saharan black Africans entrenched a dispossession of hegemonic masculinity's qualities and resources, making them useless, helpless, ${ }^{34}$ or irrationally violent actors. They are 'poor', 'desperate', 'afraid', 'trapped', or 'brutal mercenaries', 'on the front line'. In this way sub-Saharan migrants are subordinated when represented as marginalized masculinities: in fact, not only gender, but also class and race play an integral part in the construction of manhood. As it is stated by Connell (2005), "Race relations may become an integral part of the dynamic between masculinities. In a white-supremacist context [as the media discourse turned out to be from this analysis], black masculinities play symbolic roles for white gender construction” (Connell, 2005: 80). Following this line, it is possible to explain the functionality of this construction of sub-Saharan migrants for Gaddafi's international negotiations, for the rebels' claim on the need for international intervention, and for the validation of the role of the international community - including media and journalists. ${ }^{35}$ Additionally, explanations of migrants' insecurity and vulnerability to violence are rooted in the negation of Western ideals by actors involved in the conflict. Also, the normalization of victimhood and danger impedes the development of alternative accounts more centred on the migrants' voices, because - within this hierarchy

34 See for example AJ (I), (2), (4), (7), and NYT (7).

35 The modern profession of journalism finds its origins in the Enlightenment period and so is usually associated with Western values and forms. 
of masculinities - experiences and needs expressed by migrants themselves as well as their role as political actors are undermined. On the contrary, migrants' voices appear in media merely to support facts or opinions presented by journalists: the existence of sub-Saharan migrants is not seen independently from the Western presence; it is through media that sub-Saharans prove their existence and living conditions. Both ways of classifying $^{36}$ sub-Saharans, as well as the logic presented, become functional for justifying international intervention in the conflict and the contemporary regime of migration control as the main instruments for guaranteeing human security. The hegemonic model of masculinity is then the one reproduced and legitimized in media representations through the silencing of subSaharan voices or by contrasting them with (or by the celebration of) Western values, with their ideals of democracy and economic wealth.

Concluding the analysis, we note that media representations of different forms of masculinities - within the narratives presented - worked to construct an idea of security linked to dominant modern Western values, including liberal democracy, market-based economies, rationality, and expertise. Norms and behaviours associated to masculinity reinforced these propositions. Following Bourdieu's understanding of symbolic violence, we see that it is the normalization of vulnerability as well as hostility towards sub-Saharan work as a form of symbolic violence that makes reflections on and questions about the current dominant conception of security and the actions undertaken from this perspective difficult. In fact, the media legitimization of RtoP as normative frame shifts the attention beyond the state as a protector, to include for example international agencies and NGOs. However, it undermines the role of sub-Saharan migrants as political actors, in so far as the media limited the understanding of bottom-up initiatives to security initiatives (Huysman/Squire 2009). In short, media discourse during the Libyan conflict supported the implementation of RtoP and limited the possibilities for its critical discussion. ${ }^{37}$

Further, we have highlighted that responses to situations of diffused insecurity have been seen as proceeding almost entirely from Western capacity and values, as well as the Western paternalistic and heroic predisposition to help others. However, in repeated situations these urgent humanitarian actions ignored the needs and circumstances of sub-Saharan migrants'

36 As mercenaries or as vulnerable population.

37 See for example Forte (20IIa). insecurity, generating questionable gaps in the effectiveness of those actions as adequate protection. This is the case for the Western management of the migration crisis, which we argue has not stopped migrants' insecurity or mobility, but led to the death of many sub-Saharans due to the prioritization of control and borders over the rights of asylum, protection, ${ }^{38}$ free mobility, and so on. We raise serious doubts about the possibility of fostering migrants' security through these types of actions and discourses, including the representations that they entail in terms of migrants' identities and needs. Moreover, categorizations are usually coupled with justifications of past or future actions (Leudar/Marsland/Nekvapil 2004). Finally, we conclude that mainstream media representations played a central role in the construction of gendered, racial, and class-based categorizations that undermined the possibilities for debating social justice beyond the dominant frames of security and migrants' stereotypes.

\subsection{Conclusion}

Investigating the links between migration, the media representation of masculinities, and human security, this chapter aimed to show the relevance of intersectional analysis in illuminating the complexity of the conditions of insecurity faced by vulnerable groups in conflict situations. The concept of intersectionality elaborated by Crenshaw has proved to be a useful tool for studying how power relations at political, representational, and cultural levels affect not just women's conditions, but also those of other social groups in marginal positions. Moreover, the understanding of different levels of intersectionality as a continuum, where different knowledge and spheres interact, ${ }^{39}$ allowed an examination of the symbolic representations as elements influencing structural and institutional levels and vice versa. The triple jeopardy situation is reflected for example in how the role of migrants is conceived by job market forces and institutions, influencing the ways in which the presence of migrants in Libya is understood by policymakers pushing for the endorsement of different kinds of state migration pol-

38 This is the case with asylum seekers who were returned to their country of origin, the lack of assistance for boats at risk, and the prioritizing of detention centres over adequate living conditions in a life-threatening context.

39 Leudar, Marsland and Nekvapil (2004) make reference to the concept of 'dialogical network' to refer to the links that exist between various media events and that are created by different actors around the world. 
Table 13.2: Media representations of masculinities during the 2011 Libyan conflict. Source: the authors.

\begin{tabular}{|c|c|c|}
\hline Models of masculinity & Associated to & Characterized by \\
\hline Hegemonic masculinity & $\begin{array}{l}\text { Associated to western actors and embodied } \\
\text { by the figures of aid workers, professionals } \\
\text { of the international community, entrepre- } \\
\text { neurs and corporate managers. }\end{array}$ & $\begin{array}{l}\text { Rationality, expertise, wealth, moral } \\
\text { strength, courage, generosity, capacity for } \\
\text { self-sacrifice. }\end{array}$ \\
\hline Complicit masculinity & $\begin{array}{l}\text { Associated to the Rebels, and embodied by } \\
\text { Gaddafi's opposition, stakeholders of the } \\
\text { new regime, notables, businessmen, profes- } \\
\text { sionals, exiles. }\end{array}$ & $\begin{array}{l}\text { Proactivity, determination, courage, care for } \\
\text { others, advanced education, need to be sup- } \\
\text { ported. The 'lack' of knowledge and strate- } \\
\text { gies for violent actions. }\end{array}$ \\
\hline Subordinated masculinity & $\begin{array}{l}\text { Associated to Gaddafi's loyal forces and } \\
\text { embodied by Gaddafi himself. }\end{array}$ & Irrationality, cruelty, cowardice, proactivity. \\
\hline Marginalized masculinity & $\begin{array}{l}\text { Associated to sub-Saharans in Libya and } \\
\text { embodied by the poor black migrants. }\end{array}$ & $\begin{array}{l}\text { Poverty, desperation, victimhood, irrationa- } \\
\text { lity, aggressiveness. They are politically under- } \\
\text { mined and have a lack of agency capacity. }\end{array}$ \\
\hline
\end{tabular}

icies in the country and elsewhere; this would in turn affect foreign workers' quality of life and media information regarding actors involved in migration flows. In the Libyan case, the structural conditions of vulnerability of sub-Saharans have been understood by media as motives to represent migrants as either passive victims or dangerous subjects, and this became an impediment to identifying solutions that addressed the need for the dignified protection of migrants within particular life-threatening circumstances.

Further, the possibility to observe this type of dynamics offered by intersectional analysis has also enabled us to put the spotlight on the symbolic violence embedded in media discourses about who should be protected and by whom, which strongly require questioning, deconstruction, and reflection. In fact, looking critically at media's construction of identities, we observed that the proposed set of categorizations served to discriminate groups of civilians and normalize an understanding of selective protection which, for instance, favoured expatriate staff from the international community' over migrant workers and refugees. The timeline of organized evacuations for migrants at the beginning of the conflict is one example of this trend. Thus, acknowledging that civilians are not a homogeneous group but are divided along sociocultural and legal boundaries, we argue that media discourses rhetorically approached the problems of those structurally disadvantaged and legitimized selective protection of the better-off. In sum, media have been an actor and an instrument contributing to insecurity.

In terms of media responsibility it is difficult to make conclusive proposals. The debate about the possibilities of changing journalists' practices has been long-lasting and the prioritization of different elements - regulatory practices, material resources, knowledge, sources of information, political agendas, and ethics involved, among others - has led to a multiplicity of positions. One of the authors argues from a socio-constructivist perspective for the importance and urgency of promoting normative regulations concerning the use of specific categories that reinforce symbolic violence and cultural stereotypes of contempt for the black race or marginal groups, particularly within a context of conflict. Her reasoning, in line with APS (1997) recommendations, also implies processes of cultural awareness within which one's media should "take responsibility for representing ethnic groups, ethnic differences and conflict between ethnic groups, in ways which highlight the diversity within groups and similarities across groups, thereby discouraging stereotyping" (APS, I997: 42). The other author shares the importance of undermining the circulation of racializing and racist discourses, but is sceptical about the capacity of regulatory practices to change the editorial choices of mainstream media and their shareholders, and considers that any regulation would instead run the risk of increasing the legitimation of mainstream media practices. She instead makes a claim for supporting independent and self-organized media that make explicit the standpoint from which they speak. In line with Harding's (I993) ideas of strong objectivity, she suggests moving beyond ideas of neutrality in journalism, which often translate objectivity as being a white, bourgeois, and male standpoint, and favours editorial projects ${ }^{40}$ which ac-

40 Examples of independent and self-organized media might be the Spanish Diagonal; at: <http://www.diagonalperiodico.net/-Quienes-somos-.html $>$ or the PanAfrican Pambazuka; at: 〈http://www.pambazuka.org/ en/about.php>. 
knowledge biases and openly discuss their approach to social justice (Durham, I998).

To discuss the issues of migrants' security, the Libyan context provides a meaningful case of analysis to illuminate the consequences of migration policies in conflict situations. In fact, this country has been one of the first involved in the process of the externalization of EU border control. Further, regulations producing the illegality of migrants and the restriction of mobility have not only worked to relegate migrants to situations of precariousness and marginality in peaceful times. These regulations also impeded migrants' safe escapes during conflicts and suspended people's lives for the indeterminate period of being held in refugee camps. As the deaths in the Mediterranean showed, the EU regime of migration control does not foresee the possibility of accessing airports for sub-Saharan workers in Libya (Kumar 20II). Nor does it allow the mobilization of resources, knowledge, and relations outside the rules of humanitarian emergencies.

Reflecting on the guarantees offered by the normative frame of RtoP is important because, as an ex- isting mechanism to protect civilians, it failed in the Libyan case to provide safeguards for sub-Saharan migrants. Instead of suggesting concrete alternative understandings of security, we emphasize the importance of promoting further research to identify mechanisms and practices of protection from a bottom-up perspective. Intersectional analysis can prove to be a useful tool for empirical studies that move beyond universalistic standpoints and instead search for migrants' own understanding of security. We would encourage the Arendtian approach of 'right to have rights' as the right of those in insecure situations to choose what security might signify for them and how it would be possible to improve their conditions (Oman 20I0). Doing so may also imply generating discourses and practical alternatives to the unilinear mainstream media's narratives on how things 'should be'. From this perspective, we argue for a future with open possibilities to practise alternatives to Western liberal democracy market-based economies, and the related understanding of security, that makes possible a human life with dignity.

Table 13.3: Articles analysed

\section{Al Jazeera articles}

1. "Libya migrants' plight 'desperate': British minister demands 'unfettered access' to help thousands of migrants fleeing violence amid anti-Gaddafi uprising"; at: <http://www.aljazeera.com/news/africa/2011/03/201135165632260669. html>.

2. "Migrants suffer in Tripoli camps: Black Libyans and migrants are stuck in Tripoli in squalid conditions and threats of violence"; at: <http://www.aljazeera.com/news/africa/2011/09/201191102134823327.html>.

3. "Migrants forced to fight for Gaddafi: 'They said we must stay to fight when the Americans come', a Ghanaian worker tells Al Jazeera from a refugee camp"; at: <http://www.aljazeera.com/indepth/features/2011/04/2011481 8291705627.html>.

4. "Migrants 'fleeing Libya' drown off coast: Bodies of some 70 Eritrean asylum seekers fleeing the conflict are reported to have been found off the coast", at: <http://www.aljazeera.com/news/europe/2011/04/ 201143201853574844.html>.

5. "The day the Katiba fell: Libya's turning point may have come when protesters overwhelmed a barracks in Benghazi", at: <http://www.aljazeera.com/indepth/spotlight/libya/2011/03/20113175840189620.html>.

6. "Tales from the front: A Libyan rebel speaks: Who are Libya's fighters? And can they defeat Gaddafi? An injured rebel says yes, but military analysts aren't so sure"; at: <http://www.aljazeera.com/indepth/features/2011/04/ 20114922636100124.html>.

7. "African migrants targeted in Libya: Rights groups fear dozens killed in violent backlash against supposed Gaddafihired mercenaries from sub-Saharan Africa". With video (2:10min); at: <http://www.aljazeera.com/news/africa/ 2011/02/201122865814378541.html>.

8. “Libya no-fly zone supporters push for UN vote: Washington says the Security Council may need to take measures that go beyond a no-fly zone in Libya"; at: <http://www.aljazeera.com/news/africa/2011/03/201131715122293202. html>.

9. "Sins of the father, sins of the son: While Gaddafi has relied on empty revolutionary slogans to maintain power, his son looks to oil money for his"; at: <http://www.aljazeera.com/indepth/opinion/2011/02/201122271939751816. html>.

10. "Scores killed in Libya tribal clashes: Fighting in southern town of Sabha has killed more than 70 people as African tribe says it is facing a 'massacre'"; at: <http://www.aljazeera.com/news/africa/2012/03/201232901547564337. html>. 


\section{The Guardian articles}

1. "Libya: Britain sends planes to help with mass airlift of refugees"; at: <http://www.guardian.co.uk/world/2011/mar/ 02/libya-britain-sends-planes-refugees?INTCMP=SRCH>.

2. "300 migrants feared dead after boat capsizes off Sicily"; at: <http://www.guardian.co.uk/world/2011/apr/06/300migrants-feared-dead-sicily? INTCMP=SRCH>.

3. "Gaddafi targets relief ship as it evacuates Misrata wounded in Libya"; at: <http://www.guardian.co.uk/world/2011/ may/04/gaddafi-targets-relief-ship-misrata-libya?INTCMP=SRCH>.

4. "Aircraft carrier left us to die, say migrants"; at: <http://www.guardian.co.uk/world/2011/may/08/nato-ship-libyanmigrants>.

5. "Libyan regime accused of exploiting boat people"; at: <http://www.guardian.co.uk/world/2011/may/11/libyaaccused-of-exploiting-humanitarian-crisis? INTCMP=SRCH>.

6. "Refugees from Libya attacked in Tunisian desert"; at: <http://www.guardian.co.uk/world/2011/may/25/libya-refugees-gaddafi-regime-attacked>.

7. "Helping Libya's refugees is the better way to beat Gaddafi"; at: <http://www.guardian.co.uk/commentisfree/2011/ may/11/libya-refugees-gaddafi-african-migrants? INTCMP $=S R C H>$.

8. "Italy demands to know if Libya blockade warship ignored refugees"; at: <http://www.guardian.co.uk/world/2011/ aug/05/nato-ship-ignored-libyan-refugees-claim?INTCMP=SRCH>.

9. "Tripoli facing three-sided advance by the Libyan rebels"; at: <http://www.guardian.co.uk/world/2011/aug/19/ tripoli-facing-advance-libya-rebels>.

10. "Libya's spectacular revolution has been disgraced by racism"; at: <http://www.guardian.co.uk/commentisfree/ 2011/aug/30/libya-spectacular-revolution-disgraced-racism?INTCMP=SRCH>.

\section{New York Times articles}

1. "Refugee Agency Reports 'Humanitarian Emergency' as Multitudes Flee Libya"; at: <http.//www.nytimes.com/ 2011/03/01/world/europe/01 refugee.html?_r=1\&ref=libya>.

2. "Many Refugees From Libya Don't Want to Go Home"; at: <http://www.nytimes.com/2011/03/10/world/africa/ 10migrants.html>.

3. "250 Migrants Missing After Boat Sinks Off Italy"; at: <http://www.nytimes.com/2011/04/07/world/europe/ 07migrants.html>.

4. "On Ship of Evacuees From Libya, Harrowing Tales"; at: <http://www.nytimes.com/2011/04/19/world/africa/ 19 evacuees.html>.

5. "The Killing Seas"; at: <http://www.nytimes.com/2011/05/19/opinion/19lucht.html>.

6. "The Lives at the End of the Rockets' Arc"; at: <http://www.nytimes.com/2011/05/06/world/africa/ 06misurata.html>.

7. "NATO Crew Failed to Aid Migrant Ship, Survivors Say"; at: <http://www.nytimes.com/2011/08/06/world/africa/ 06refugees.html>.

8. "New Fighting Outside Tripoli as Foreigners Seek an Exit"; at: <http://www.nytimes.com/2011/08/20/world/africa/ 20libya.html>.

9. "Libyans Turn Wrath on Dark-Skinned Migrants"; at: <http://www.nytimes.com/2011/09/05/world/africa/ 05migrants.html?_r=1>.

10. "Accused of Fighting for Qaddafi, a Libyan Town's Residents Face Reprisals"; at: <http://www.nytimes.com/2011/ 09/24/world/africa/accused-of-fighting-for-qaddafi-tawerga-residents-face-reprisals.html>.

\section{References}

Aguilar, Delia, 20I2: "Tracing the Roots of Intersectionality", in: MRzine a project of the Monthly Review Foundation; at: <http://mrzine.monthlyreview.org/20I2/ aguilarI204I2.html> (2I May 20I2).

Altunisik, Meliha, I996: "A rentier state's response to oil crisis: economic reform policies in Libya", in: Arab Studies Quarterly, I8,4.
Anthias, Floya, 2007: "Boundaries of 'Race' and Ethnicity and Questions about Cultural Belongings", in: Gopalkrishnan, Narayan; Babacan, Hurriyet (Eds.): Racism in the New World Order: Realities of Cultures, Colours and Identity (New Castle: Cambridge Scholars Publishing): I2-20.

APS (Australian Psychological Society), I997: "Racism and Prejudice: Psychological Perspectives”, Position Paper; at: <http://www.psychology.org.au/Assets/Files/racism _position_paper.pdf>, 25 April $20 \mathrm{I2}$. 
Bourdieu, Pierre, 1977: Outline of a theory of practice (Cambridge: Cambridge University Press).

Branchet, Julien, 20II: "The Blind Spot of Repression: Migration Policies and Human Survival in the Central Sahara", in: Truong, Thanh-Dam; Gasper, Des (Eds.): Transnational Migration and Human Security: The Migration-Development-Security Nexus (Berlin - Heidelberg: Springer): 57-66.

Bürkner, Hans-Joachim, 20I2: "Intersectionality: How Gender Studies Might Inspire the Analysis of Social Inequality among Migrants", in: Population, Space and Place, I8,2: I8I-I95.

Carey, Henry, F., 200I: "Women and Peace and Security: the Politics of Implementing Gender Sensitivity Norms in Peacekeeping", in: International Peacekeeping, 8,2: 49-68.

CARIM (Consortium for Applied Research on International Migration) [written by Anna Di Bartolomeo, Thibauot Jaulin and Delphine Perrin], 20II: Migration Profile: Libya (Florence: European University Institute, Robert Schuman Centre for Advanced Studies)

Carpenter, R., Charli, 2005: "Women, Children and Other Vulnerable Groups: Gender Strategic Frames and the Protection of Civilians as a Transnational Issue", in: International Studies Quarterly, 49,2: 295-334.

Carrigan, Tim; Connell, Bob; LeeReviewed, John, I985: "Toward a New Sociology of Masculinity", in: Theory and Society, I4,5: 5I-604.

Chatora, Arthur, 20II: "Mainstream Media Coverage of Libya Disturbing", at: <http://www.iss.co.za/iss_today. php? ID $=$ I37O $>$ (29 April 20I2).

CHS (Commission on Human Security); UNOPS (United Nations Office for Project Services), 2003: Human Security Now (New York: UNOPS Communications Development in Washington, DC)

Connell, Robert, I998: "Masculinities and Globalization", in: Men and Masculinities, I,3: 3-23.

Connell, Robert, 22005: Masculinities (Cambridge: Polity Press).

Crenshaw, Kimberlé, W., I99I: "Mapping the Margins: Intersectionality, Identity Politics, and Violence against Women of Color", in: Stanford Law Review, 43,6: I24II299.

Das, Veena, 2008: "Violence, Gender, and Subjectivity", in: Annual Review of Anthropology, 37: 283-299.

Del Grande, Gabriele, 20IIa: "Generazione revolution: da Benghazi a Lampedusa”, at: <http://fortresseurope. blogspot.com/20II/o3/generazione-revolution-da-benghazi.html> (29 March 20I2).

Del Grande, Gabriele, 20Irb: "Un'altra strage: morti 65 eritrei, i superstiti accusano la Nato"; at: <http://fortresseurope.blogspot.com/20II/04/i-sette-superstiti.html> (29 March 20I2).

Del Grande, Gabriele, 20IIc: "Tra due fuochi. Gli stranieri in Libia al tempo della rivoluzione"; at: <http://fortresseurope.blogspot.com/20II/04/tra-due-fuochi-glistranieri-in-libia.html> (29 March 20I2).
De Haas, Hein, 2008: "The myth of invasion: the inconvenient realities of African migration to Europe", in: Third World Quarterly, 29,7: I305-I322.

De Haas, Hein, 20I2: "The Arab Spring and Migration"; at: <http://heindehaas.blogspot.com/20I2/03/arab-springand-migration.html> (I4 April 20I2).

Didero, Maike, 20II: "Media images and everyday realities: German-Moroccan perspectives on translocational positionalities", Paper presented at the international RC2I conference The struggle to belong: Dealing with diversity in $2 \mathrm{I}^{\text {st }}$ century urban settings, Amsterdam, 7-9 July 2OII

Durham, Meenakshi, Gigi, I998: "On the Relevance of Standpoint Epistemology to the Practice of Journalism: The Case for Strong Objectivity", in: Communication Theory, 8,2: II7-I40.

Forte, Maximilian, 20IIa: "The top ten myths in the war against Libya”, in: News, 27 October 20II; at: <http:// pambazuka.org/en/category/features/77439> (20 January 20I2).

Forte, Maximilian, 20Irb: "The War in Libya: Race, 'Humanitarianism', and the Media”, in: News, 20 April 2OII; at: <http://mrzine.monthlyreview.org/20II/forte 2004II.html> (20 January 20I2).

Fraser, Nancy, 2009: Scales of Justice: Reimagining Political Space in a Globalizing World (New York: Columbia University Press)

Fudge, Judy, 20Io: "A Question of Scale: Justice, Citizenship and Gender", in: Canadian Journal of Women and the Law, 22,I: 267-276.

Fukuda-Parr, Sakiko; Messineo, Carol, 20I2: "Human Security: A Critical review of the Literature", in: Centre for Research on Peace and Development (CRPD) Working Paper No II, Belgium; at: <http://soc.kuleuven.be/ web/files/I2/80/wpII.pdf>,(I5 February 20I2).

Garelli, Glenda; Tazzioli, Martina, 20II: "Esistenze sospese e resistenze al CARA di Mineo"; at: <http://www.storiemigranti.org/spip.php?rubriqueI26> (29 March 20I2).

Gasper, Des, 20I0: "Climate Change and the Language of Human Security”, Working Paper 505 (The Hague: International Institute of Social Studies (ISS)).

Global Detention Project, 2009: "Libya Detention Profile"; at: 〈http://www.globaldetentionproject.org/countries/ africa/libya/introduction.html>, Io February 2012.

Gopalkrishnan, Narayan; Babacan, Hurriyet, 2007: "Introduction: "Race" and Racism", in: Gopalkrishnan, N.; Babacan, H. (Eds.): Racism in the New World Order: Realities of Cultures, Colours and Identity (Cambridge: Cambridge Scholars Publishing): I-8.

Hall, Stuart, 1997: "The Work of Representation”, in: Stuart Hall (Ed.): Representation: Cultural Representations and Signifying Practices (London: Sage Publications).

Hamood, Sara, 2008: "African transit migration through Libya to Europe: the human Cost", in: Journal of Refugee Studies, 2I,I: 19-42.

Harding, Sandra, I993: "Rethinking Standpoint Epistemology: What is 'Strong Objectivity'?", in: Alcoff, Linda; 
Potter, Elizabeth (Eds.): Feminist Epistemologies (New York: Routledge): 49-82.

Heathcote, Gina, 20II: "Feminist Politics and the Use of Force: Theorising Feminist Action and Security Council Resolution I325”, in: Socio-legal Review, 7: 23-43.

Hill, Felicity; Aboitiz, Mikele; Poehlman-Doumbouya, Sara, 2003: "Nongovernmental Organizations' Role in the Buildup and Implementation of Security Council Resolution I325”, in: Signs, 28,4: I255-I269.

Hoogensen, Gunhild; Stuvoy, Kirsti, 2006: "Gender, Resistance and Human Security", in: Security Dialogue, 37: 207-228.

Hooper, Charlotte, 2008: Manly States: Masculinities, International Relations and Gender Politics (New York: Columbia University Press).

Hudson, Heidi, 2005: "Doing Security As Though Humans Matter: A Feminist Perspective on Gender and the Politics of Human Security", in: Security Dialogue, 36,2: 155I74.

Hudson, Natalie, 20I0: "Gender, Human Security, and the United Nations: Security Language as a Political Framework for Women" (London: Routledge).

Huliaras, Astereis, 200I: "Qadhafi's comeback: Libya and sub-Saharan Africa in the I990s", in: African Affairs, IOO: 5-25.

Huysman, J.; Squire, V., 2009: "Migration and Security", in: Dunn Cavelty, M.; Mauer, V. (Eds.): Handbook of Security Studies (London: Routledge).

ICRtoP, 20I2: "Crisis in Libya. International Coalition for the Responsibility to Protect”; at: <http://www.responsibilitytoprotect.org/index.php/crises/crisis-in-libya?format $=\mathrm{pdf}>$ (I3 June 20I2).

IMI, 20II: North Africa in Transition: Mobility, Forced Migration and Humanitarian Crises (Oxford: International Migration Institute).

IOM, 20I2: Migrants Caught in Crisis: The IOM Experience in Libya (Genève, Switzerland, International Organization of Migration)

Johnson, Trevor, 2000: "Ethnic violence and mass deportations of immigrants in Libya"; at: <https://www. wsws. org/articles/2000/oct2000/liby-028.shtml> (I5 February 20I2).

Kristoffersson, Ulf, 2000: HIV/AIDS as a Human Security Issue: A Gender Perspective, Working Paper Expert Group Meeting (city: United Nations Programme on HIV/AIDS).

Koser, Khalid, 20II: Responding to Migration from Complex Humanitarian Emergencies: Lessons Learned from Libya, Briefing Paper (London: Chatham House, Centre on Global Health Security).

Kumar, Richa, 20II: "Not in my Backyard: Externalization Practices of the EU and its impact on the Refugee Protection Regime" (MA Thesis, University of Amsterdam, Graduate School of Social Studies).

Leudar, Ivan; Marsland, Victoria; Nekvapil, Jiri, 2004: “On Membership Categorization 'us', 'them' and 'doing vio- lence' in Political Discourse”, in: Discourse \& Society, I5,2-3: $243-266$.

Lorentzen, Lois Ann; Turpin, Jennifer, I998: “The Woman and War Reader" (New York: New York University Press).

Marshal, Andrew, Gavin, 20II: "Lies, War and Empire: NATO 'Humanitarian' Imperialism in Libya”; at: <http://georgewashington2.blogspot.com/20II/o8/lies -war-and-empire-natos-humanitarian.html> (27 April 2012).

McKay, Susan, 2004: "Reconstructing fragile lives: Girls' social reintegration in Northern Uganda and Sierra Leone" in: Gender and Development, I2,3: 19-30.

Migreurop, 20II: "At the Margins of Europe: the Externalization of Migration Controls"; at: <http://www.statewatch.org/news/20I2/mar/migreurop-annual-report20IO-20II.pdf> (30 March 20I2).

Mohanty, Chandra Talpade, I991: "Under Western Eyes: Feminist Scholarship and Colonial Discourse", in: Mohanty, Chandra Talpade; Russo, Ann; Torres, Lourdes (Eds.): Third World Women and the Politics of Feminism (Indianapolis: Indiana University Press): 333-358.

Oman, Natalie, 20I0: "Hannah Arendt's 'Right to Have Rights': A Philosophical Context for Human Security”, in: Journal of Human Rights, 9,3: 279-302.

O'Reilly, M; Parker, N., 20I2: "Unsatisfactory Saturation: a critical exploration of the notion of saturated sample sizes in qualitative research", in: Qualitative Research; at: <http://qrj.sagepub.com/content/early/20I2/05/ I7/I468794II2446I06.abstract> (I4 August 20I2).

Paoletti, Emanuela, 20II: "Migration and foreign policy: the case of Libya", in: The Journal of North African Studies, I6,2: 2I5-23I.

Pezzotti, Maddalena, 2005: "Women, Peace Processes and Peacekeeping Operations: A Conflict Management Perspective", in: Conflict Trends, I: I9-22.

Reisigl, Martin; Wodak, Ruth, 200I: Discourse and Discrimination: Rhetorics of racism and anti-Semitism (London - New York: Routledge)

Ronzitti, Natalino, 2009: “The Treaty of Friendship, Partnership and Cooperation between Italy and Libya: New Prospects for Cooperation in the Mediterranean?", Paper presented at the Mediterranean Strategy Group Conference on "Is regional cooperation in the Maghreb possible? Implications for the Region and External Actors", Genoa, II-I2 May.

Saxer, Marc, 2008: "The Politics of Responsibility to Protect”, in: Dialogue on Globalization, Briefing Paper, No. 2 (Berlin: Friedrich Ebert Stiftung [FES]).

Scheffran, Jurgen; Brzoska, Michael; Brauch, Hans, Gunter; Link, Peter, Michael; Schilling, Janpeter (Eds.), 20I2: Climate Change, Human Security and Violent Conflict: Challenges for Societal Stability. Hexagon Series on Human and Environmental Security and Peace, vol. 8 (Heidelberg - Dordrecht-London-New York: Springer).

Titscher, Stefan, 2000: Methods of Text and Discourse Analysis"(London: Sage). 
Truong; Thanh-Dam, 2009: Feminist knowledge and Human Security: Bridging Rifts through the Epistemology of Care, Working Paper No. 48I (The Hague: International Institute of Social Studies [ISS]).

Tucker, Bruce; Triantafyllos, Sia, 2008: "Lynndie England, Abu Ghraib and the New Imperialism”, in: Canadian Review of American Studies, 38,1: 83-100.

United Nations, 20II: "Security Council SC/IO200: $6498^{\text {th }}$ Meeting" (New York: United Nations, Department of Public Information); at: <http://www.un.org/News/ Press/docs/20II/scIO200.doc.htm> (I5 February 20I2).

UNCHR, 20I2: "More than I,500 drown or go missing trying to cross the Mediterranean in 20II", in: News Stories, 3I January 20I2; at: 〈http://www.unhcr.org/4f280 3949.html> (23 May 20I2).

UNCHR, 20II: "Internal displacement on the rise in Libya, UNHCR sending aid to Benghazi”, Briefting Notes, 22 March 20II; at: <http://www.unhcr.org/4d888f3d9. html>, 30 March 2012.

UNCHR, 20IIa: "UN High Commissioner for Refugees appeals for safety of third-country nationals in Libya", Press Release, 22 August; at: <http://www.unhcr.org/ 4e526I069.html> (I5 April 20I2).
UNHCR, 20Irb: "UNHCR concerned as sub-Saharan Africans targeted in Libya”, Press Release, 26 August 20II; at: <http://www.unhcr.org/4e57dicb9.html> (I5 April 20I2).

Yuval-Davis, Nira, 2006: "Intersectionality and Feminist Politics", in: European Journal of Women's Studies, I3,3: 193-209.

Vassallo Paleologo, F., 20II: "Dall'emergenza umanitaria allo Stato d'eccezione” (city: Associazione Studi Giuridici sull'Immigrazione); at: <http://www.asgi.it/public/parser _download/save/commento.dall.emergenza.umanitaria. allo.stato.di.eccezione.fulvio.paleologo.pdf > (27 August 20I2).

Walby, Sylvia; Armstrong, Jo; Strid, Sofia, 20I2: "Intersectionality: Multiple Inequalities in Social Theory" in: Sociology, 46,2: 224-240.

Zarkov, Dubravka, 20II: "Exposures and Invisibilities: Media, Masculinities and the Narratives of War in an Intersectional Perspective," in: Lutz, H.; Herrera, M.T. Vivar; Supik, L. (Eds.): Framing Intersectionality: Debates on a multi-faceted Concept in Gender Studies (Farnham: Ashgate): I05-I2O.

Open Access. This chapter is distributed under the terms of the Creative Commons Attribution Non-commercial License, which permits any noncommercial use, distribution, and reproduction in any medium, provided the original author(s) and source are credited. 